\title{
HISTORICAL KNOWLEDGE-GENRE AS IT RELATES TO THE REUNIFICATION OF CAMEROON IN SELECTED ANGLOPHONE CAMEROONIAN HISTORY TEXTBOOKS
}

\author{
DOI: http://dx.doi.org/10.17159/2223-0386/2017/n18a3
}

Raymond Nkwenti Fru

University of KwaZulu-Natal

Edgewood Campus

nkwentifru80@gmail.com
Johan Wassermann

Honorary Professor, History Education

University of KwaZulu-Natal

Johan.wassermann@up.ac.za

\section{Abstract}

Since the 1961 reunification of French and British Southern Cameroons, discourses of marginalisation, assimilation, "francophonisation", "frenchification" and internal colonisation have emerged in public and academic circles to describe the plight of the minority Anglophone population of Cameroon in the reunified country. An important element of this plight has been the systematic abrogation of the federal constitution that was adopted as basis for the reunification. The calls therefore from the Anglophone populations have mostly revolved around two options: Either a return to federal form of government which was the basis for reunification or the establishment of an autonomous state for Southern Cameroons.

Against this backdrop of Anglophone plight linked to reunification, this study sought to analyse Anglophone Cameroonian History textbooks with regards to their application of historical genres and knowledge as it relates to the reunification of Cameroon. The study adopted a qualitative approach using an interpretivist paradigmatic lens. The methodology employed was qualitative content analysis of three purposively selected Anglophone Cameroon History textbooks. The findings revealed that the textbooks employ explanatory, narrative and descriptive historical genres. These genres were all characterised by factorial and consequential explanations of actions of elite historical characters, selected historical events, and places. Furthermore, it was realised that the textbooks made use of a highly overt substantive form of historical knowledge in the explanation of reunification a form of historical knowledge indicative of rote learning. Lastly, there was an evident discourse of an Anglophone identity or nationalism in the textbooks by function of the historical genre and knowledge types exposed.

Keywords: Anglophone; Cameroon; Historical genre; Historical knowledge; Reunification; Textbooks. 


\section{Introduction}

Cameroon is one of few countries that witnessed official colonisation by three European powers at different times in its history. It is also one of only two countries in the world, the other being Canada, that presently use both English and French as national official languages. The country has as a colonial legacy two sub-systems of education and a bi-jural legal system to accommodate its Anglophone and Francophone populations.

Before the arrival of the European colonisers the territory and people that make up present day Cameroon existed as sovereign ethnic entities. The beginning of Cameroon as a conglomerate of states under colonial administration started with German colonial rule in 1884. This lasted for 30 years during which period Germany "negotiated and established the country's international boundaries, set up the institutions for modern administration and gave rise to the idea of belonging together or being Cameroonian amongst the people of the various ethnic groups and traditional states of the territory" (Fanso, 1999:282). However, with the defeat of the Germans during World War 1 Cameroon was portioned between Britain and France in an agreement that saw the former and the latter receive respectively one-quarter and three-quarters of the territory (Awasom, 2000; Fanso, 1999; Njeuma, 1995). Scholars such as Awasom (2000) and Konings and Nyamnjoh $(1997 ; 2000)$ have argued to the effect that this disproportionate partitioning of Cameroon was the foundation of a future Anglophone minority and a Francophone majority. This became a crisis in the reunified Cameroon of 1961 with claims of marginalisation emanating from Anglophone Cameroonians. In light of the above, it can be insinuated that the process of reunification of 1961, and the post-colonial nation-state (re) construction, were bound to be challenging from the perspective that "separate colonial state formation $[\mathrm{s}]$ and the development of territorial differences in languages and cultural legacies [had] laid the spatial and historical foundation for the construction of Anglophone and Francophone identities" (Awasom, 2002; Konings \& Nyamnjoh, 2003:10).

The post-World War II era witnessed a spirit of decolonisation that swept across the African continent. This trend was succinctly articulated on 3 February 1960 by the then British Prime Minister, Harold Macmillan while addressing the South African parliament in Cape Town. Macmillan encouraged his government to adopt a policy of decolonisation and referred to the winds of change that was blowing across Africa as a political fact (Ovendale, 1995). From a Cameroon perspective, the decolonisation process 
led to France granting independence to French Cameroon on 1 January 1960 whilst on the other side a plebiscite was organised in the British Southern and Northern Cameroons on 11 February 1961 on whether the people would want to achieve independence by joining Nigeria or French Cameroon. With the outcome of the plebiscite for British Southern Cameroons being in favour of reunification, the French and British Cameroons were reunified on 1 October 1961. Meanwhile Northern British Cameroon voted in the plebiscite to join Nigeria and was accordingly integrated into the Sarduana province of northern Nigeria (Fombad, 2011). However, contrary to Anglophone expectations, reunification was far from providing an equal partnership between Anglophones and Francophones. It turned out to be nothing but absorption, assimilation, marginalisation, and exploitation of the Anglophone minority by the Francophone dominated state and by the Francophone population as a whole (Konings \& Nyamnjoh, 2003; Konings \& Nyamnjoh, 1997/2000).

It is against this background of post-reunification tension in post-colonial Cameroon that this article set out to explore the nature of the historical genre and historical knowledge in selected Anglophone Cameroonian History textbooks as it relates to Cameroonian reunification. The following research question underpins this study: What is the historical genre-knowledge in Anglophone Cameroon History textbooks as it relates to reunification?

In order to address this research question, this article constitute of the following sections: a review of literature on reunification and textbooks as the focal phenomena for this study; issues of methodology; analysis of the data and findings; discussion of the findings; and conclusion of the study. It is also necessary to point out that the findings and discussions of this study were viewed through a postcolonial lens.

\section{Literature review}

The key substantive concepts at the focus in this article are reunification and History textbooks. The literature reviewed was consequently divided into two sections.

\section{Reunification}

From a conceptual angle reunification is understood differently in different circles. Tromble (2007:4) used the word "reconnecting" in a social welfare context when he referred to reunification as a "process of reconnecting 
children in foster care with their families". This understanding is similar to the view of Jarausch (2010:501) who examined reunification from a geopolitical perspective and came to the conclusion that reunification refers to "a restoration of the natural state of things as they had been, before the division". The implication of the above mentioned conceptualisation is twofold: Firstly, reunification may manifest in different forms, for example, social and/or political and, secondly, for it to occur there had to have been a pre-existing union prior to the division, partition or separation of the entity in question. Thus, reunification may be understood as the reunion or reintegration of a family, a group of people, a nation or a state that had, as a result of certain circumstances in the past, been caused to split. In the context of this study, the notion of reunification refers to the reintegration into a nation state of different political entities that had been united as a people at some point in the past but were later partitioned and caused to separate, either in accordance with their own free will as a result of internal factors or else involuntarily as a result of an imposition on the inhabitants.

According to Hart-Landsberg (2009), it is not possible to view reunification as an unambiguously good process but, rather, it should be viewed as a highly contested procedure. This ambiguity explains the controversial discourses that often emerge in countries that have experienced reunification or are hoping to achieve it. The examples in this regard include North and South Korea, Somalia and Somaliland, and West and East German. In the sections below, we present the German case study of reunification scenarios as it relates to that of Cameroon.

One major consequence of the surrender of Germany in 1945 and the armistice that followed was a decision taken at the Teheran conference by the principal world powers to the effect that the defeated Germany be governed jointly by a four-power military commission, with Berlin as a separate but similarly administered entity (Ritter \& Hajdu, 1989). The partition of Germany started with a decision by the USA, Great Britain and France to amalgamate their zones into a Federal Republic of Germany - FRG (West Germany) in September 1949. This was followed in the next month by the establishment of the German Democratic Republic - GDR (East Germany) in the Soviet zone of Germany. The establishment of the FRG and the GDR signified the beginning of a permanent partition of Germany into two states with different political and ideological orientations (Ritter \& Hajdu, 1989). In August 1961, the partition between East and West Germany was 
consolidated and reinforced with the erection of a Berlin Wall. This partition of Germany is synonymous to the partition of German Cameroon between Britain and France during the course of World War I which formed the basis of the reunification that came about in 1961.

In line with the circumstances of its partition as seen above, the German reunification that happened in 1989/1990, manifested as a peaceful revolution, especially on the part of the East German citizens of the GDR (Jarausch, 2010). From the East German perspective, therefore, it was hoped that reunification would be the solution to their political and economic misery. This view is not dissimilar to those held by the Southern Cameroonians upon reunifying with French Cameroon (Konings \& Nyamnjoh, 2000/2003). In support of this view, Behrend (2011:61) contends that many of the GDR citizens who had voted for German unity had done so with the expectation that, in a short time, their situation would match that of their West German counterparts. However, this was not to be. Two decades after reunification, reunified Germany is still a divided country along West and East Germany lines, with claims of discrimination emanating from former GDR citizens (Behrend, 2011:64) who felt they bore the "brunt of German reunification" (Scholz, 1994:108). Thus, in view of the above, the experience of the reunification of Germany has been described in certain circles as merely the one-sided and fast absorption of East Germany by West Germany (Hart-Landsberg, 2009). This description puts the Germany scenario on par with that of Cameroon in terms of the claims of marginalisation and assimilation of the Southern Cameroons in the reunified Cameroon. These claims are made against the context of Cameroon still largely being divided along lines of Anglophone and Francophone lines.

\section{Textbooks}

From a pedagogic perspective, Lin, Zhao, Ogawa, Hoge and Kim (2009), argue that History textbooks remain, in most countries, the most powerful means with which to provide people with an understanding of their own History as well as that of the world. Thus, History textbooks remain a significant source of pedagogical content knowledge for both teachers and learners with these textbooks providing an organised system of ideas and information and, thereby, helping to structure the teaching and learning of History (Sewall, 2004). In addition Pingel (2010:30) notes that "textbooks provide expertise, are time savers, and provide security for both teachers and 
students in outlining content, scope and sequence". The indispensable nature of textbooks is seen in the fact that teachers in many instances rely on the textbooks as central to their teaching.

However, in spite of the fact that textbooks are vital instructional resources, some scholars have questioned their neutrality stating, for example, that textbooks do not transmit facts and information or knowledge only but also norms, rules of societies and ideologies (Sakki, 2010). Additionally, textbooks also "seek to anchor the political and social norms of a society" (Schissler, 1989-1990:81). In support of this Apple and Christian-Smith (1991:3) submit that "texts are not simply delivery systems of facts. They are at once the result of political, economic and cultural activities, battles, and compromises. They are conceived, designed, and authored by people with real interest. They are published within the political and economic constraints of markets, resources and power". This side of the role of History textbooks evokes the question of the underlying purpose of History education. Maric (2016) has problematized this further by asking if the purpose of History education is to build critical, active, and responsible citizens? If so it should choose a historical genre and knowledge around sensitive and controversial topics to develop critical thinking, so as for learners to acquire the concept of multi-perspectivity, while developing the ability to foster dialogue. On the other hand, he continues that if History education serves simply to transfer certain preconceived, one-sided narratives, then it excludes the variety of experiences and dialogue on interpretations, and does not foster inquiry. This depiction of the dual face of History education speaks to textbooks because it is through these constructed resources that the goal of History education is many a time fostered.

Scholars such as Lin et al. (2009) and Polakow-Suransky (2002) have acknowledged that History textbooks, in particular, and textbooks in the humanities and social sciences in general, incorporate certain attitudes and ways of looking at the world. In these textbooks, particular opinions and interpretations are presented (Schissler, 1989-1990). This suggests that textbooks do not deserve their reputation as impartial tools that simply teach learners facts and skills. Rather, the suggestion is that textbooks are always politically sensitive. And as Schissler (1989-1990) points out that if examined in accord with these premises, then textbooks can be an excellent resource with which to analyse social and historical consciousness's. The political nature of textbooks is supported by Engelbrecht (2006:3) who argues that 
"textbooks embody the selective tradition - it is always someone's vision of legitimate knowledge and culture, one that in the process of enfranchising one group's cultural capital disenfranchises another's". Textbooks thus seek to enforce and reinforce cultural homogeneity and promote shared attitudes and historical memories, and consequently involve a struggle over public memory (Crawford, 2000).

\section{Methodology}

This was a qualitative study whose focus was on revealing the historical genres and knowledge types in Cameroonian Anglophone History textbooks. A qualitative approach was adopted because of the need for an in-depth, intricate and detailed understanding of the reunification phenomenon by means of depth rather than quantification (Creswell, 2009). We therefore assumed the interpretivist paradigm with the view of understanding the nature of these genres and knowledge types as represented in the selected textbooks. Stevens, Schade, Chalk \& Slevin (1993) submit that research carried out in the interpretivist paradigm is called qualitative research. This position clarifies the link between the choice of approach and paradigm for this study. The methodology that we employed was qualitative content analysis. This was done since our purpose was to compress the text on reunification into categories, based on explicit rules of coding (Stemler, 2001). The three Anglophone Cameroonian History textbooks that constituted the sample for this study were purposively chosen on the basis that they each contain a chapter or section dealing with reunification. It was those specific sections of the textbooks that were considered for the analysis of the historical genres and knowledge. Table 1 below shows the details of the three textbooks that we purposively selected for the study.

\section{Table 1: Showing sampling of Anglophone Cameroonian History textbooks}

\begin{tabular}{|l|c|l|l|}
\hline AUTHOR & YEAR & TITLE & PLACE/ PUBLISHER \\
\hline Fanso, V. G & 1989 & $\begin{array}{l}\text { Cameroon history for secondary } \\
\text { schools and colleges. Vol. 2: The } \\
\text { colonial and post-colonial periods }\end{array}$ & London, Macmillan \\
\hline Victor Julius Ngoh & 1996 & History of Cameroon since 1800 & Limbe, Presprint \\
\hline Tazifor Tajoche & 2003 & $\begin{array}{l}\text { Cameroon history in the } 19^{\text {th }} \text { and } \\
\text { 20 }\end{array}$ & $\begin{array}{l}\text { Buea, Education Book } \\
\text { Centre }\end{array}$ \\
\hline
\end{tabular}


All the textbooks were approved in the official Cameroonian textbooks list for the 2014/2015 academic year (document: No 0614/MINESEC/CAB). It is also important to note that all three textbooks have been selected at least once in the official textbooks lists for Anglophone Cameroonian schools over the past five academic years. Moreover, the General Certificate of Education (GCE) syllabus also officially recommends these textbooks for the teaching of History in Anglophone schools.

In this study, we have attributed colour codes to the three textbooks mentioned above. These codes were used for the analysis and for the discussion. We refer to Cameroon history for secondary schools and colleges. Vol. 2: The colonial and post-colonial periods, as the Green Book; History of Cameroon since 1800 as the Red Book; and Cameroon history in the 19th and 20th centuries as the Blue Book. Apart from the convenience factor in the coding, these colours are representative of the original colours on the cover pages of the respective selected textbooks. The units of analysis comprised of both visual and verbal text. Visual and verbal texts in this study were taken as features that play complementary and collaborative rather than exclusive roles in a text (Hagan, 2017; LaSpina, 1998; Wu, 2014).

The qualitative content analysis instrument employed consisted of specific historical genre and knowledge methods as will be explained below. Coffin (2006) submits that History, like other school subjects, has a specific language and that each piece of writing in history has a distinct purpose relating to wider disciplinary practices, which she titles as 'genre' (p. 1). The genre here signifies the manner in which the text is written for the purpose of communicating its message to its audience. This could be in the form of style, structure, choice and placement of content such as headings, visuals, or tables. The identification of the text genre served as a springboard for the analysis by situating the text within a certain category of historical writing from where it was possible to then understand the historical knowledge types propagated. This implies that the historical genre type was not considered in isolation from the historical knowledge types but rather was seen as the building blocks of this dualistic relationship of historical genre-historical knowledge type. The process of identification of the historical genre types of the text involved a combination of the typology of history genres as seen in Table 2 below which allowed genres to be classified according to the type(s) that appeared in the textbooks. 
Table 2: Historical genres - An adaptation from Martin (2007:57)

\begin{tabular}{|c|c|c|}
\hline Genre type & Sub-genre & Description \\
\hline $\begin{array}{l}\text { Autobiographical recount: } \\
\text { One sided narrative }\end{array}$ & \multirow{2}{*}{$\begin{array}{l}\text { Recording or } \\
\text { explaining genre }\end{array}$} & $\begin{array}{l}\text { The story of my life (oral } \\
\text { History) }\end{array}$ \\
\hline $\begin{array}{l}\text { Biographical narrative: } \\
\text { Third person/Alternative side }\end{array}$ & & The story of someone else's life \\
\hline \multirow{2}{*}{$\begin{array}{l}\text { Historical Account: } \\
\text { Explaining/Argumentative/ } \\
\text { Interpretation genre }\end{array}$} & Factorial explanation & $\begin{array}{l}\text { Complexifying the notion of } \\
\text { what leads on to what }\end{array}$ \\
\hline & $\begin{array}{l}\text { Consequential } \\
\text { explanation }\end{array}$ & $\begin{array}{l}\text { Complexifying the notion of } \\
\text { what leads on from what }\end{array}$ \\
\hline $\begin{array}{l}\text { Many people } \\
\text { One-sided and multi-sided } \\
\text { perspective }\end{array}$ & Exposition & $\begin{array}{l}\text { Problematic interpretation that } \\
\text { needs justification }\end{array}$ \\
\hline
\end{tabular}

In line with the historical genre, the historical knowledge of the texts on reunification was considered in light of the substantive and procedural forms of knowledge as summarised in the Table 3 below.

\section{Table 3: Substantive and procedural historical concepts (adapted from Martin, 2012:8)}

\begin{tabular}{|c|c|}
\hline cal concepts & Procedural historical concepts \\
\hline $\begin{array}{l}\text { - Substantive concepts refer to subject } \\
\text { matter and content knowledge of } \\
\text { - History in the form of key terms, } \\
\text { themes, actors and events. } \\
\text { - Also known as propositional } \\
\text { knowledge or first order concepts of } \\
\text { History. } \\
\text { - It is the content or substance of } \\
\text { History. } \\
\text { - It represents the statements of facts } \\
\text { of History. } \\
\text { - It focuses on historical themes, } \\
\text { actors. }\end{array}$ & $\begin{array}{l}\text { - Procedural concepts are specific methods and } \\
\text { procedures that give disciplinary structure. } \\
\text { - They contribute to the construction of } \\
\text { substantive knowledge. } \\
\text { - They consist of skills for structuring and } \\
\text { giving sense and coherence to events in } \\
\text { history. } \\
\text { - This is also known as know-how history or } \\
\text { second order concepts and include: cause and } \\
\text { effects; historical significance; historical time; } \\
\text { historical empathy; contextualisation. } \\
\text { - They are the conceptual tool needed for } \\
\text { the study of the past as a discipline and the } \\
\text { construction of the content of historical } \\
\text { knowledge. }\end{array}$ \\
\hline
\end{tabular}


Lévesque (2008) has conceptualised historical knowledge as dependent on two intertwined, interdependent and complementary (not conflicting) strands of knowledge: substantive and procedural knowledge. In his view, while substantive knowledge of History refers to factual, narrative and descriptive content of historical events, procedural knowledge on the other hand deals with the systematic, methodical processes involved in understanding History. Typically, substantive knowledge of History is found in expectations of students' learning, such as the students' understanding of certain terms, events, phenomena, or personages while procedural knowledge concentrates on the concepts and vocabulary that provide the structural basis for the discipline (Lévesque, 2008). Procedural concepts are not what History is about, the substance. They are the conceptual tools needed for the study of the past as a discipline and the construction of the content of historical knowledge. Ultimately, procedural forms of historical knowledge are more desirable for modern History teaching and learning by virtue of its emphasis on enquiry skills and multi-perspectivity.

Using the analytical tools of historical genres and knowledge the findings were compared across the three textbooks. The aim was to produce firm findings so as to answer the research question posed.

\section{Analysis}

\section{The Green Book}

The text of the Green Book adopted a historical genre type that falls under the category of explanation and narrative creation. The use of the explanatory genre was seen to incorporate factorial and consequential descriptions to support the reunification narrative. The result was a clear absence of argumentative or interpretive explanations. This historical genre style was also achieved through a narrative text structure that impedes possibilities for engagement with the text. Moreover, the narrative and explanatory process of the text involved the use of clear chronological time markers for events and activities related to reunification. The timeline of events as described and explained in the text started from an early date and progressed sequentially through to later dates. The fact that these dates are included in the topics and sub topics on reunification indicates that their application is purposive rather than by chance. Furthermore, an analysis of the historical participants identified within the explanatory genre indicates the use of specific and generalised participants. Through the foregrounding of three high profile 
politicians throughout there is a sense of an acknowledgement of the role of big men as the driving force of the reunification process to the exclusion of ordinary Cameroonians. This finding is corroborated by the visual text whereby only Cameroonians of the elite class are depicted in the various reunification related images. Conversely, these big men worked within specific established structures such as the United Nations that were identified in the text as generalised participants.

In terms of historical knowledge, the text failed to expressly identify and make use of procedural concepts of History in its presentation of reunification. This absence is an indication that the text promotes rote learning and in the context of reunification it was seen that such knowledge are aligned with the aim of grooming submissive citizens who will uncritically submit to the master narrative on reunification rather than challenging it. The possibility here is that any form of challenge will cause chaos and disrupt social harmony between Anglo and Francophone Cameroonians. The Green textbook is therefore not a neutral disseminator of historical knowledge on reunification but rather an active accomplice to the agenda of the government to create a certain kind of citizenry.

Notwithstanding this lack of overt promotion of procedural knowledge, the analysis of the text revealed a certain incidental use of procedural concepts that were only possible to understand through an analysis of their implied use within the text. It was through this process that procedural concepts such as cause and effect, historical time, and historical significance were analysed within the text. However, because their use is incidental rather than purposive, it supports the earlier claim that the text promotes a substantive form of historical knowledge rather than its procedural opposite. This is coupled with the fact that the other more critical procedural concepts such as use of sources/ evidence, change and continuity, historical empathy or perspective taking could not be found in the text even through the analysis of their implied use.

There is therefore a visible link between the historical narrative and explanatory genre type and the historical substantive knowledge types used in the text in that the explanatory genre supports and is in turn supported by the use of substantive concepts. This historical genre-knowledge type link and consistency also has implications for the nature of school History in Cameroon and the role of textbooks and reunification. There is an presence of a chauvinistic discourse established through the domination of male characters and the complete silencing of female historical figures. In line 
with the previous point, there is also a discourse of exclusion seen through the silencing of the subaltern and the domination of political and traditional elites in the reunification process.

\section{The Red Book}

The first finding from the Red Book is that the text falls within a purely explanatory historical genre category, and is consequently void of possibilities for argumentation and interpretation. The text is largely narrative and descriptive and are characterised by explanations that are factorial and consequential in nature. This is in addition to the fact that the text comprises of verbal material with a complete absence of visual text. The nature of presentation of the narrative text is done in a very simplistic bullet, list and numbered format which supports and strengthens the argument of its focus on factorial and consequential explanations. Such genre type was seen as an attempt to promote factual historiography on the reunification with the implication that it denies the learner opportunities for engaging critically with the text and various historical possibilities. In this regard the content must be accepted as the truth without contestation. It is therefore intended for memorisation rather than engagement in a disciplinary manner.

The domino effect of the nature of historical genre type in the text is that it implies a concentration on substantive concepts of History at the expense of the procedural ones. This finding means that the text makes explicit and elaborate usage of first order concepts in its factorial and consequential narrative on the activities around reunification such as the actions of the main protagonists, and historical events and places. In foregrounding substantive concepts, the text makes use of specific and generalised participants but also unique and organisation concepts and does so in a purposively narrative using a clear chronological frame to avoid nuancing the representation. By foregrounding influential people such as traditional rulers and politicians and giving them agency, there is an effort to expose the learners to knowledge on the reunification that is centred on the actions of big men.

However, in spite of this clear and explicit substantive knowledge focus the findings also uncovered certain elements of procedural historical knowledge implicitly embedded within the narrative. The following procedural knowledge types were uncovered in the text: the idea of historical time; historical causation; historical significance; and change and continuity. Without being explicitly expressed, these procedural concepts were seen to contribute in a 
covert manner to advancing the understanding of the reunification narrative in the text of the Red Book. But because their usage is not clearly spelled out, we take it that the intention of the author was not to highlight their importance but rather to simply advance the factual information through substantive knowledge. It was found that the text follows a clear chronology of events that is supported with the use of relevant dates. Even though these dates are not directly linked to the broader picture on reunification, it is still easy to implicitly pick out that the events follow each other in the manner in which they occurred. Moreover, using Partington's (1980) idea of historical significance, certain events were seen to be represented as being more significant than others in the process of reunification. Analysed in terms of importance, profundity, quantity, durability and relevance (Partington, 1980), the Milner-Simon agreement to partition former German Kamerun and February 1961 were the two historical moments presented in the text as highly historically significant. Furthermore, there was evidence of the second order historical concept of change and continuity. The one example used to demonstrate this concept is the 1961 plebiscite in British Cameroons whose outcome served as a statement of intent for British Southern Cameroons to reunify with French Cameroon and for the Northern Cameroons to integrate with Nigeria. The implementation of the statement of intent through political negotiations overseen by the United Nations changed the political future of these territories and took their destinies in different directions. The fact that this situation has survived post-colonial turbulences makes it very relevant as an example to describe the covert use of the concept of change and continuity in the text. Conclusively, the knowledge type of the text was analysed as highly substantive but with the implicit use of some second order procedural concepts.

\section{The Blue Book}

The first finding in terms of genre is that the text of the Blue Book is written in a factorial and consequential explanatory genre category. This historical genre promotes common sense understanding of reunification that is for the effect presented in factual, numbered and bulleted explanations.

The historical genre type has implications for the form of historical knowledge used in the text. A factorial and consequential explanatory genre is most likely to promote substantive knowledge. The text of the Blue Book was seen to promote a substantive knowledge of History through a presentation 
of reunification in the form of facts and first order concepts. The substantive knowledge was analysed in terms of unique and organisational concepts. The unique concepts revealed the names of individual persons used in the text. These persons were seen to be of the categories of politicians and the traditional elite therefore raising the point that these people were the role players in reunification. The unique concepts were also considered in terms of the places mentioned in the text and the events highlighted. The majority of places mentioned were linked the plebiscite that was also important in presenting a breakdown of the plebiscite results. This added to the significance of the plebiscite as an event. Apart from the substantive concepts that were explicitly used in the text, certain procedural concepts could also be deduced from the text. Second order procedural concepts such as causation, time, and change and continuity were identified in the text. Summarily, in terms of the text historical genre and knowledge type it could be said that the findings are interrelated such that one contributes to the other and the other helps explain and understand the one. To be more specific, the factorial and consequential explanatory text genre relates to a substantive version of historical knowledge as the explanations themselves constitute second order unique and organisational concepts.

\section{Discussion and findings}

The historical genre analysis of the Anglophone textbooks produced a common pattern - that being that they all adopted, with reference to reunification, a summative master narrative consisting of a factorial and consequential explanatory genre. This implies the existence in the selected Anglophone textbooks of a historical genre that emphasises simplistic agreed upon explanations by means of listed causes and consequences together with other related factual information on reunification. In spite of this general pattern across all three Anglophone textbooks, the manner in which the different textbooks adopted and applied the explanatory genre differed slightly. The differences lie in the fact that, while in the Green Book the explanatory historical genre is reflected in a narrative format of the text as a story that can be read and understood, both the Red and Blue textbooks applied the explanatory genre in the form of lists and bullets. This marks the explanatory genre of the Red and Blue Books as simplistic and exclusively aimed at rote learning. However, all three Anglophone textbooks presented a genre of history that aimed at presenting facts rather than opportunities for engagement by means of historical thinking on reunification. 
Another comparative element of the historical genre type of the Anglophone History textbooks is their use of visual text in the form of pictures. The analysis revealed that both the Green and the Blue Book made use of visual text whilst the Red Book ignored this form of textual representation. This implies that the history of reunification is seen in the Red Book merely as a form of written text serving the purpose of memorisation and retention. Nonetheless, visual textual reunification content used in the two instances as explained did not give opportunities for the visuals to serve any interpretative purposes. This means that the visual texts were only meant to complement the narrow explanatory functions of the verbal text thereby reinforcing that historical genre type.

Another factor worth mentioning as a function of the historical genre of the selected Anglophone textbooks is that all three constitute narrations of the actions of influential people related to reunification. Even though it was seen in the books that influential people from Anglophone Cameroons were foregrounded at the expense of those of Francophone Cameroons, the argument remains that the books ignored the contributions of ordinary Cameroonians in the process of reunification. This is also true of the idea that these historical actors are predominantly male thereby insinuating that female characters, just like other ordinary Cameroonians, were insignificant players in the reunification process.

With the underlying historical genre for all the Anglophone textbooks being factorial and consequential explanatory, narrative, descriptive and simplistic, the implication is that the Anglophone textbooks are rigorous in their rigidity in their presentation of reunification. Such factual rigidity further implies that the purposes of the Anglophone textbooks on reunification are to present the content as truthful and agreed upon and meant for consumption by the learners with acceptance and without questioning and thinking. There is therefore a penchant towards a single narrative of reunification which in a nutshell says history is not provisional and open to debate. Consequently, in the Anglophone textbooks other historical genre types that could disrupt such a narrative were not engaged with.

A question that can be asked here is why the authorship of the sampled Anglophone textbooks would prefer the presentation of reunification from the perspective of the explanatory historical genre when, as the literature reviewed earlier in this article, revealed claims of marginalisation of the Anglophone population within the (re)union (Awasom, 2002; Fanso, 1999; 
Konings \& Nyamnjoh, 2003). The answer to this question probably lies in some of the characteristics of postcoloniality. In this regard, the postcolonial theory reveals that subalternism was a practice whereby the previously colonised elites, such as the textbook authors in the context of this study transformed themselves into the new colonisers over their compatriots upon the attainment of formal independence - a situation that the theory also refers to as internal colonisation (Hamadi, 2014; McClintock, 1993; Tosh, 2009; Walia, 2001). By adopting a historical genre in post-colonial Anglophone texts that does not seek to uncover ideological representations, the authors and publishers of the Anglophone textbooks are creating a subaltern group in their learners through exclusiveness, silencing of their voices and any other histories or simply by creating a top-down approach to history. From this perspective the Anglophone textbooks and their authorship, in terms of the historical genre adoption, are post-colonial but far from being postcolonial where the former concept is linked to time frame after official colonisation and the latter referring to prevalent colonial conditions (coloniality) after the official end of colonisation (Hitchcock, 1997; McLeod, 2000). This is largely so because of their failure to adopt historical genres that encourage critical historical thinking on reunification and that integrate sociocultural approaches to history that would give the subalterns a voice. Therefore, in this state of affairs, the complicity seem to lie with the state as much as the authors who take aim at premising History education and Cameroonian reunification around nationalistic and patriotic agendas rather than as a critical endeavour. Consequently, the historical genres of the selected Anglophone textbooks could be seen to be inclined tom a discourse of Anglophone nationalism, as a form of resistance to the political status quo - a phenomenon that is akin to and typical of post-colonial Africa.

Comparing and contrasting the historical knowledge types of the three Anglophone books shows that there was a clear link between the historical genre adopted and the nature of historical knowledge of the texts. This implies that each genre had implications for the kind of historical knowledge that the particular text espoused. It emerged that all the Anglophone textbooks adopted an overt and explicit use of the substantive form of historical knowledge with regard to their representation of reunification. This aligns with the explanatory historical genre as the genre specificity for all the texts. The indication was therefore that Anglophone Cameroonian textbooks encouraged a factual explanation of the content of reunification without any opportunities to engage with different narratives and perspectives. In line 
with the substantive knowledge emphasis of all the textbooks, the trend was also that different elements of second order procedural concepts were used in all the textbooks in an incidental rather than purposeful manner. Some of the procedural concepts found in the textbooks included cause and effect, historical significance and change and continuity. However, used incidentally implied that the textbooks did not intend to promote those concepts as a form of historical knowledge that students should acquire as a result of studying reunification but that the concepts only emerged incidentally as a part of the textual narratives. The consequences of a substantive form of historical knowledge was that the Anglophone textbooks promoted established narratives on the reunification that foregrounded Southern Cameroons and protected such narratives through not giving opportunities for learners to form their own opinions and to critique the text through different procedural historical thinking engagements. This leaves learners and teachers of History vulnerable to the ideas of the authors and producers of these textbooks who are able to teach their ideas and perspectives on the reunification largely unchallenged.

Further, a trend was observed in all three Anglophone textbooks on the use of unique substantive concepts related to representation of people. In this regard, we noticed that for all the Anglophone books, the unique substantive people mentioned all fell within the categories of political figures and traditional rulers. These people, who could be referred to as "big or influential men" were presented by these texts as the main architects of reunification. What the focus on these "big men" also implied was that the textbooks did not consider any role of ordinary citizens or women as historically significant in the reunification endeavours. The argument could therefore be made that the Anglophone textbooks in terms of the application of unique substantive historical knowledge related to people, displayed a form of elitist and patriarchal or male chauvinistic history that denied a historical voice to the Cameroonian subaltern. Taking this further, was the consideration of the regional extraction of these political figures and traditional authorities represented in the texts. The analysis of the unique substantive concepts in terms of people further indicated that the political figures and traditional authorities highlighted in the texts were largely of Southern Cameroons' extraction and very few were from French Cameroon. What this reveals is that the textbooks present reunification as the active efforts of Southern Cameroonians and a passive French Cameroon participation. This was interpreted as an attempt by the Anglophone texts to promote Anglophone nationalism through their depiction of the reunification process as driven solely or largely by Anglophone efforts. 
That being the case, the Anglophone textbooks could therefore be implicitly sending a message that issues related to reunification, including contemporary ones, should be resolved by the Anglophone community considering that the process from its beginnings was controlled by them.

Another finding that emanated from the analysis is a discourse on Anglophone nationalism and identity. The question here is why would Anglophone textbooks push forward an agenda that is more pro Anglophone than pro national in terms of the Cameroonian nation state? As a start, we recall HartLandsberg (2009) who suggested that it is not possible to view reunification as an unambiguously good process but, rather, it should be viewed as a highly contested process. Going by this it could be argued that the nationalism advocacy depicted in the textbooks is in line with the nuanced nature of the reunification project generally. The desire to promote an Anglophone identity could be explained in terms of the perceived marginalisation of the Anglophone Cameroonians by the Francophone Cameroonians in a majority dominated Francophone Cameroon. This marginalisation was captured by authors such as Awasom (2000); Chem-Langhëë (1995); Fanso (1999); Konings and Nyamnjoh (2003). The argument presented by the above authors is that the federation that followed reunification was a sham federation which, although safe for appearances, was actually a preparatory stage for the annexation of Southern Cameroons through the assimilation of their territory into a highly centralised Francophone unitary state. Therefore, it could be argued that the quest for an Anglophone identity and the promotion of Anglophone nationalism as revealed in the historical genre and knowledge of the Anglophone textbooks could be explained as part of the Anglophone resistance to their perceived marginalisation and treatment as second class citizens in reunified Cameroon as well as to counter the "Frenchification" efforts of the Francophone led regime.

\section{Conclusion}

This study employed a qualitative content analysis methodology in the analysis of three purposively selected Anglophone Cameroon History textbooks with regards to their representation of historical genres and knowledge as it relates to the reunification of Cameroon. The findings revealed that the textbooks employ explanatory, narrative and descriptive historical genres. These genres were all characterised by factorial and consequential explanations of actions of elite historical characters, selected historical events, and places. Furthermore, 
it was realised that the textbooks made use of a highly overt substantive form of historical knowledge in the explanation of reunification - a form of historical knowledge indicative of rote learning. Lastly, there was an evident discourse of an Anglophone identity or nationalism in the textbooks by function of the historical genre and knowledge types exposed. This study revealed that Anglophone textbooks in Cameroon have not followed the trend in other countries of progression from a substantive to a procedural view of historical knowledge. Through promoting highly substantive form of historical knowledge and explanatory genre, the textbooks ensured that the single intended narrative of an Anglophone identity and nationalism on reunification could be disseminated unchallenged.

\section{References}

Apple, M \& Christian-Smith, L 1991. The politics of the textbook. In: M Apple \& L Christian-Smith (eds.). The politics of the textbook. New York: Routledge.

Awasom, NF 2000. The reunification question in Cameroon history: Was the bride as enthusiastic as the groom? Africa Today, 47(2):90-119.

Awasom, NF 2002. Negotiating federalism: How ready were Cameroonian leaders before the February 1961 United Nations plebiscites? Canadian Journal of African Studies / Revue Canadienne des Études Africaines, 36(3):425-459.

Behrend, H 2011. Viewpoints on German partition and reunification. Social Semiotics, 21(1):55-65.

Chem-Langhëë, B 1995. The road to the unitary state of Cameroon 1959-1972. Paideuma, 41:17-25

Coffin, C 2006. Historical discourse: The language of time, cause and evaluation. London: Continuum.

Crawford, K 2000. Researching the ideological and political role of the history textbook - Issues and methods. International Journal of History Learning, Teaching and Research, 1(1):1-8.

Creswell, J 2009. Research design. Qualitative, quantitative and mixed methods approaches (3 ${ }^{\text {rd }}$ edition). Los Angeles: SAGE Publications, Inc.

Engelbrecht, A 2006. Textbooks in South Africa from apartheid to post apartheid: Ideological change revealed by racial stereotyping. Available at www.web.worldbank.org. Accessed on 16 November 2010. 
Fanso, V 1999. Anglophone and Francophone nationalism in Cameroon. The Round Table, 350:281-296.

Fombad, CM 2011. National monographs - Cameroon. In: A Alen \& D Haljan (eds.). International Encyclopedia for Constitutional Law. The Hague: Kluwer Law International.

Hagan, SM 2017. Visual/verbal collaboration in print complementary differences, neccesary ties, and an untapped rhetorical opportunity. Written Communication, 24(1):49-83.

Hamadi, L 2014. Edward Said: The postcolonial theory and the literature of decolonisation. European Scientific Journal [Special Edition], 2:39-46.

Hart-Landsberg, M 2009. The promise and perils of Korean reunification. Monthly Review, 1:50-59.

Hitchcock, P 1997. Postcolonial Africa? Problems of theory. Women's Studies Quarterly, 25(3/4):233-244.

Jarausch, KH 2010. Beyond the national narrative: Implications of reunification for recent German history. German History, 28(4):498-514.

Konings, P \& Nyamnjoh, FB 1997. The Anglophone problem in Cameroon. The Journal of Modern African Studies, 35(2):207-229.

Konings, P \& Nyamnjoh, FB 2000. Construction and deconstruction: Anglophones or autochtones? The African Anthropologist, 7(1):5-32.

Konings, P \& Nyamnjoh, F 2003. Negotiating and Anglophone identity: A study of the politics of recognition and representation in Cameroon. Leiden: Brill.

LaSpina, JA 1998. The visual turn and the transformation of the textbook. Mahweh, NJ: Lawrence Erlbaum Associates.

Lévesque 2008. Thinking historically: Educating students for the twenty first century. Toronto, Canada: University of Toronto Press.

Lin, L, Zhao, Y, Ogawa, M, Hoge, J \& Kim BK 2009. Whose history? An analysis of the Korean war in history textbooks from the United States, South Korea, Japan and China. Social Studies, 100(5):222-232.

Maric, D 2016. The homeland war in Croatian history education: Between "real truth" and innovative history teaching. In: D Bentrovato, K Korostelina \& M Schulze (eds.). History can bite: History education in divided and postwar societies. Gottingen: V \& R Unipress. 
Martin, JR 2007. Constructing knowledge: A functional linguistic perspective. In: F Christie \& J Martin (eds.). Language, knowledge and Pedagogy: Functional linguistic and sociological perspectives. London: Continuum.

Martin, G 2012. Thinking about Historical Thinking in the Australian Curriculum: History. Victoria: University of Melbourne.

McClintock, A 1993. The angel of progress: Pitfalls of the term "Post-colonilaism". In: RJ Patrick Williams \& L Chrisman (eds.). Colonial discourse and post-colonial theory: A reader. Hemel Hempstead: Harvester Wheatsheaf.

Mcleod, J 2000. Beginning postcolonialism. Manchester: Manchester University Press.

Njeuma, MZ 1995. Reunification and political opportunism in the marketing of Cameroon's independence. Paideuma, 41:27-37.

Ovendale, R 1995. Macmillan and the wind of change in Africa, 1957-1960. The Historical Journal, 38(2):455-477.

Partington, G 1980. The idea of an historical education. Slough: NFER.

Pingel, F 2010. UNESCO guidebook on textbook research and textbook revision, (2nd revised and updated ed.). Braunschweig: UNESCO.

Polakow-Suransky, SS 2002. Historia amnesia? The politics of textbooks in post-apartheid South Africa. Paper presented at the Annual meeting of the American Educational Research Association, New Orleans, LA.

Ritter, G \& Hajdu, J 1989. The East-West German boundary. Geographical Review, 79(3):326-344.

Sakki, I 2010. A success story or a failure? Representing the European intergration in the curricular and textbooks of five countries. Unpublished Ph.D. thesis. Helsinki: University of Helsinki.

Sewall, GT 2004. World history textbooks: A review. Paper presented at the American textbook council, New York.

Schissler, H 1989-90. Limitations and priorities for international social studies textbook research. The International Journal of Social Education, 4(3):81-89.

Scholz, H 1994. East-West women's culture in transition: Are East German women the losers of reunification? Journal of Women's History, 5(3):108-116.

Stemler, S 2001. An overview of content analysis. Practical Assessment, Research \& Evaluation, 7(17). Available at http://PAREonline.net/getvn.asp? $=7 \& n=17$. Accessed on 9 November 2013. 
Stevens, P, Schade, A, Chalk, B, \& Slevin, O 1993. Understanding research: A scientific approach for health care professionals. Edinburgh: The Alden Press.

Tosh, J 2009. The pursuit of history. London: Routledge.

Tromble, K 2007. Reunification definitions: To promote consistency in state data reporting for the timeliness of reunification federal outcome measures: Child Welfare League of America. National Working Group to Improve Child Welfare Data (NWG).

Walia, S 2001. Postmodern encounters. Edward Said and the writing of history. London: Faber and Faber Ltd.

Wu, S 2014. A multimodal analysis of image-text relations in public books. Theory and Practice in Language Studies, 4(7):1415-1420. 